\title{
OVERCOMING CHALLENGES IN VIRTUAL CLASSROOM TO MAINTAIN EFFECTIVE CLASSROOM MANAGEMENT AND CLASSROOM CULTURE: A CASE STUDY AT ONE VOCATIONAL SCHOOL
}

\author{
Ridha Mardiani ${ }^{1}$, Ridha Nurul Azhar ${ }^{2}$ \\ ${ }^{1}$ English Study Program, Sekolah Tinggi Keguruan dan Ilmu Pendidikan Pasundan, Cimahi, \\ 40512, West Java, Indonesia \\ ${ }^{2}$ English Study Program, Sekolah Tinggi Keguruan dan Ilmu Pendidikan Pasundan, Cimahi, \\ 40512, West Java, Indonesia \\ 1ridha.mardiani53@gmail.com \\ ${ }^{2}$ ridhanurulazhar@gmail.com
}

\begin{abstract}
Effective classroom management supports the teacher classroom teaching profoundly. During Pandemic COVID 19 most classroom teachings are conducted in virtual classroom that have been greatly affected the way how teacher manage his or her own classroom. This causes some challenges for teachers in managing his or her virtual classroom. This study was conducted in the form of a case study in one vocational school in West Bandung region, West Java, Indonesia in which one English teacher was purposively selected as the participant of the research and one class consisted of 27 students. The objectives of this study are: (1) to find out the challenges of teacher in classroom management in virtual classroom (2) to find out what classroom management the teacher used in her virtual classroom. The researchers employed a qualitative case study which used classroom observation and teacher interview as main instrument. Data from classroom observation and interview transcript were analyzed according to the themes, coding and categorizing to answer the research questions. The results indicate that the teacher experienced many challenges in the virtual classroom, such as the students' unreadiness to join the virtual class, internet connection problem, restricted time so that the teacher immediately taught the core material, students turned off the camera and sound, students learnt unattentively, less interaction and inappropriate class control. Some suggestions are given to the challenges occurred in their virtual classroom such as, by a) joining the virtual classroom earlier; b) checking the students' attendance first; c) optimizing the teacher-students interaction during whilst- learning and post learning activity; and d) giving quizzes at the end of the lesson to make the students are more enthusiastic in learning. In this study, it is found that the teacher employed a combination of democratic and leisurely classroom management style. This finding leads to the point where a new style for virtual classroom management called Maye's Conceptualization Model is proposed.
\end{abstract}

\section{Keywords : classroom management, challenges, virtual classroom}

\section{Introduction}

Since the outbreak of the pandemic COVID19 , the government has taken many ways to prevent its widely spread all over area in Indonesia. This pandemic has affected all aspects of human life including education. Education desperately needs proper attention and specific treatment because of the pandemic effect on school learning activities. Then, Indonesian government issued a policy of school learning through the letter of the Ministry of Education and Culture (Kemendikbud) of the Directorate of Higher
Education Number 3 of 2020 concerning Prevention of Covid-19 in the Education Unit, and Number 36962 / MPK.A / HK / 2020 concerning Online Learning and Working from Home in the Context of COVID 19 spread prevention.

Online learning is enforced by the government due to the emergency of Covid19 spread prevention (Mutqinah \& Hidayatullah, 2020). Online learning and its implementation have affected school and classroom learning activities. Teachers and 
students must adjust to these changes immediately. Teachers and students are forced to do learning activities in virtual classroom. What is online learning? Learning that is supported by mobile devices such as smartphones, tablets and laptop which can be used to access information anywhere and anytime (Gikas \& Grant, 2013) using internet networks with accessibility, connectivity, flexibility and the ability to produce various types of learning interactions is called online learning (Moore, Deane-Dickson \& Galyen, 2011). Relevant to that understanding one research finding from Zhang et.al (2004) shows that the use of internet and multimedia technology can change the way of conveying knowledge and can be an alternative to traditional classrooms. The use of mobile technology has a major contribution in the world of education, including the achievement of distance learning goals (Korucu \& Alkan, 2011). Online learning is an alternative best solution for learning activities during Pandemic Covid 19, as it helps the students learn in a safe condition.

Despite of its best solution to the pandemic impact on education, online learning opens up to any challenges because it shifts from traditional classroom to virtual classroom which caused teachers to optimize the use of their skills in managing classroom. One of teacher's task is create conditions in which learning can take place well. This is not an easy job, since it has to do with the teacher's attitude, intentions and personality and relationships with the learners. Thus, he or she needs certain organizational skills and techniques to create, establish and maintain classroom climate in order that learning take place well. These items are often grouped together under the heading of 'classroom management' (Scrivener, 2011).

Teachers who manage their classroom effectively and discipline themselves and their students could create conducive classroom atmosphere and classroom culture. This skills of creating and managing a successful class can be the key to the whole success of learning. Teachers who can control classroom situation and classroom culture would likely to influence the students' understanding and willingness to learn. Most students will be motivated to learn when they can relate to the material. Multiple strategies will most likely appeal to the varied learning styles of modern students.

Classroom management has persistently ranked as one of the challenges for beginning teachers (Headden, 2014; Langdon, 1999; Langdon \& Vesper, 2000), largely because they do not know how to deal with disruptive students or positively assert authority (Ingersoll \& Smith, 2003; Stoughton, 2007). Even when beginning teachers recognize strategies that should be used, they struggle to effectively implement these actions in their classrooms (Range et al., 2012; Sokal et al., 2003; Westling, 2010). There are ample empirical findings on how teachers manage their onsite classroom, however only a little number of studies which investigates classroom management on virtual classroom. In traditional classroom, teachers usually explain the material in front of the class, manage seat arrangement in orderly rows, use textbook for the material and practice exercises (Setyowati, 2017). Some changes and challenges precisely occurred in virtual classroom.

However, to fill this void the researchers would like to investigate how classroom management is carried out by a vocational high school teacher in a virtual classroom. The purposes of the study are as follows: 1) to find out the challenges of teachers in classroom management in virtual classroom; and 2) to find out what classroom management the teacher uses in virtual classroom. Thus, the research problems as follows: 1) What are the teacher challenges in managing virtual classroom in a vocational high school? 2) What type of classroom management are used in virtual classroom?

\section{Method}

The research methodology used in this study is a qualitative case study design (Cresswell, 2014). Qualitative research is a research method with an interpretive approach, to gain insight into certain meanings and behaviors experienced by a person, this method uses descriptions and words to study a person's experiences and reality (Palmer \& Amanda, 2006). The goal of qualitative description is to produce a straightforward description of participants' experiences in words as similar to what the participants said as possible. 
One English teacher and one class consisted of 27 students in one vocational school were chosen purposively as the participants of this research. Furthermore, the research focuses on case management challenges in teaching English in virtual classrooms at one vocational high school. To obtain this data, virtual classroom observations and interviews are needed to identify the challenges experienced by English teachers that arise in the process of teaching English. Virtual classroom observation was carried out from November 6, 2020 to November 27, 2020 or four weeks observation in in the same class. The researchers joined the virtual classroom, observed the teaching learning process and mainly focused on how the teacher managed her classroom. In addition, the researchers identified some challenges occurred when the teacher managed her virtual classroom and categorized the notes based on the theory to answer the research questions. The researchers immersed in 'the natural setting' in this case virtual classroom, where they conducted non-participant observer during the class. They observed the phenomenon under study then make notes about the information obtained in the field directly and openly at the research location (Cresswell, 2009). Then, it was followed by the teacher interview either direct or face to face or by telephone with participant of the study. Teacher interview were conducted in the form of structured interview which mainly focused on how the teacher overcome some challenges in her virtual classroom and what type of classroom management she employed in her virtual class. After obtaining the data from classroom observation and interview transcript, the researchers analyse the data based on thematic coding and categorizing from the theory, then present it in the form of table. From data analysis, the researchers obtained the findings as follows:

\section{Tabel 1 The Result of Classroom Observation}

\begin{tabular}{|c|c|c|c|}
\hline \multirow{2}{*}{ No } & \multirow{2}{*}{ Observation } & \multicolumn{2}{|c|}{ What happened in the classroom? } \\
\hline & & Challenges & Management \\
\hline \multirow[t]{3}{*}{1.} & \multirow{3}{*}{$\begin{array}{c}\text { November 6, } \\
2020 \\
07.00- \\
07.45 \\
\text { (see } \\
\text { appendices) }\end{array}$} & $\begin{array}{c}\text { Students' } \\
\text { unreadiness }\end{array}$ & $\begin{array}{c}\text { Shared the link application } \\
\text { via WA group }\end{array}$ \\
\hline & & $\begin{array}{c}\text { Internet } \\
\text { connection. }\end{array}$ & $\begin{array}{c}\text { Check the students' } \\
\text { attendance }\end{array}$ \\
\hline & & Limited time. & $\begin{array}{l}\text { Teaching straight to the } \\
\text { point. }\end{array}$ \\
\hline \multirow[t]{6}{*}{2} & \multirow{6}{*}{$\begin{array}{c}\text { November 6, } \\
2020 \\
07.00-07.45 \\
\text { (see } \\
\text { appendices) }\end{array}$} & $\begin{array}{l}\text { Restricted } \\
\text { teaching time }\end{array}$ & $\begin{array}{c}\text { Share link application before } \\
\text { the class. }\end{array}$ \\
\hline & & $\begin{array}{l}\text { Students turn } \\
\text { off the camera } \\
\text { and sound. }\end{array}$ & $\begin{array}{l}\text { Optimizing the Teacher and } \\
\text { Students' interaction }\end{array}$ \\
\hline & & Inattentiveness & Core material \\
\hline & & $\begin{array}{l}\text { Internet } \\
\text { connection. }\end{array}$ & Random questions \\
\hline & & & Quiz \\
\hline & & & Check attendance list \\
\hline \multirow[t]{3}{*}{3.} & \multirow{3}{*}{$\begin{array}{c}\text { November } \\
20,2020 . \\
07.00- \\
07.45 \\
\text { (see } \\
\text { appendices) }\end{array}$} & $\begin{array}{l}\text { Approachwith } \\
\text { students is } \\
\text { lacking. }\end{array}$ & Virtual link \\
\hline & & $\begin{array}{l}\text { The teacher } \\
\text { cannot control } \\
\text { all students. }\end{array}$ & Friendliness \\
\hline & & & Check attendance list \\
\hline \multirow[t]{3}{*}{4.} & \multirow{3}{*}{$\begin{array}{c}\text { November } \\
27,2020 . \\
07.00- \\
07.45 \\
\text { (see } \\
\text { appendices) }\end{array}$} & $\begin{array}{c}\text { Internet } \\
\text { connection. }\end{array}$ & Share link before class \\
\hline & & & Q \& A Time \\
\hline & & & Check attendance list \\
\hline
\end{tabular}


From the observation data analysis above, we can see that the challenges faced by teachers in virtual classrooms are when the virtual class starts not all students immediately enter the class, internet connection, limited time, the teacher cannot explain in detail the material being taught due to time constraints, students turn off the camera and sound, students do not pay attention to the teacher; approach with students is lacking, and the teacher cannot control all students. To overcome challenges in virtual classrooms, teachers have several classroom management that is teacher always gives students and researchers the Google Meet link the day before class starts; the teacher checks student attendance at the beginning and at the end of the lesson; the teacher delivers the material to the point; providing material to be discussed in the virtual class 2 days beforehand through the WhatsApp class group; give random questions to students in the middle of learning, so that students stay focused and pay attention to what the teacher is saying; at the end of the lesson the teacher gives a quiz so that students are more enthusiastic and add daily scores; teachers are more friendly with students, so that students are not too bored and still excited about learning in virtual classroom.

\section{Interview}

The interview is conducted to confirm data from observation. There are four questions to be answered by the teacher. The results of the interview are as follow:

\section{Table 2 The Results of the Interview}

\begin{tabular}{|c|l|l|l|}
\hline No & \multicolumn{1}{|c|}{ Questions } & \multicolumn{1}{|c|}{ Virtual Classroom } & \multicolumn{1}{|c|}{$\begin{array}{c}\text { Traditional } \\
\text { Classroom }\end{array}$} \\
\hline 1. & $\begin{array}{l}\text { How did the teacher prepare google } \\
\text { meet for teaching learning? }\end{array}$ & $\begin{array}{l}\text { Set up and share the } \\
\text { google meet link. }\end{array}$ & Onsite \\
\hline 2. & $\begin{array}{l}\text { How did teacher prepare about lesson } \\
\text { plan, is it the same or not with traditional } \\
\text { classroom? }\end{array}$ & Restricted time. & Enough \\
\hline 3. & $\begin{array}{l}\text { Is virtual learning and offline learning } \\
\text { the same? }\end{array}$ & $\begin{array}{l}\text { Has less time } \\
\text { Students more } \\
\text { lazy, } \\
\text { Devices } \\
\text { Internet } \\
\text { Connection. }\end{array}$ & $\begin{array}{l}\text { Has longer time } \\
\text { S are more } \\
\text { enthusiastic }\end{array}$ \\
\hline 4. & $\begin{array}{l}\text { How did management challenges in } \\
\text { teaching English in virtual classroom? }\end{array}$ & $\begin{array}{l}\text { Attendance list } \\
\text { Give quiz at the } \\
\text { end of the lesson }\end{array}$ & Attendance list \\
\hline
\end{tabular}

\section{Result and Discussion}

\section{Result}

This section is greatly important for the whole research, since it presents and discusses the findings of the study. Initially the findings are stated to answer the research questions, followed by the results of data analysis and finally some other empirical findings and theories are stated to discuss the findings.

\subsection{The Challenges of Managing Virtual Classroom in Teaching English}

Research Question 1: What are the teacher challenges in managing virtual classroom in a vocational high school?

From data analysis we find that the teacher challenges in managing virtual classroom are: 1) The students' unreadiness to join the virtual class on time; 2) Internet connection problem; 3) Restricted time for teaching; 4) Students turn off camera and sound; 5) Students learnt inattentively and 6) Less interaction and inappropriate classroom control. Before we continue the discussion, the researchers need to clarify some terminologies and understanding among these: E-learning, online learning and virtual learning. Are they the same? Refer to Moore, 
Deane-Dickson \& Galyen (2011), any learning processes including web-based learning, computer-based learning, virtual and digital classroom which are delivered via internet, intranets, audio, and videotape, satellite broadcast, interactive TV, and CDROM can be called e-learning. It involves electronics means communication, education, and training. On the other hand, online learning opens to any internet accessibility whenever and wherever it is needed. This makes learning much more effective and efficient (Cole in Renggayana, 2018). While virtual classroom can be defined as learning environments that are organized or carried out online (Wang, 2001). That also means that virtual classroom is a learning system that provides opportunities for lecturers and students to carry out teaching and learning process that are outside physical boundaries of classroom walls. These opinions shared the same understanding that the teaching and learning processes are carried out through internet connection.

There are always advantages and disadvantages of shifting from traditional classroom to virtual classroom. What happened mostly in Indonesian context is that the students and teachers are consciously enforced to shift into virtual classroom where both have to adapt to the changes. Virtual classroom actually provides the same opportunities for the teaching and learning process, except it happened beyond classroom limits and classroom walls. This condition may give the students some chances to explore some facilities of the internet in order to gain meaningful learning environments. In addition, virtual classroom gave some benefits to the learners such as learning at its convenience, implementation of online tools including online calendar, online help guides, emails, chat room, etc. In addition, a virtual classroom provides learning tools, learning materials and contextual discussion (Rufai, Alebiosu \& Adeakin, 2015). Another point is that about classroom interaction which needs a live, contextual, and interactive interaction with the teacher are well accommodated in virtual classroom. On the other hand, the teacher can still have control in teaching and learning process as they have in the traditional classroom.

We can see from the interview data results that there are many challenges in managing virtual classroom, which are different from traditional classroom. The shifting from traditional classroom to virtual classroom has caused some adjustment for both party teachers and students, which in this case teachers should have control over the classroom. For teachers who are used to teaching face-to-face, facilitating online class through virtual classroom interface proposes several new challenges. The changes can cause so many challenges for teachers especially in managing virtual classroom. Challenge can be understood as condition or situation that needs mental and physical efforts in order to be accomplished successfully. Thus, it requires the teacher's ability to find solution to the challenge. The researchers think that it depends on the teacher whether she saw this shifting from traditional to virtual classroom as a challenge or an opportunity to adjust and exert her strength to create classroom atmosphere that is comfortable and conducive for learning.

As we have to acknowledge that effective teaching is established through effective classroom management. Instructional time and students' engagement are widely supported by efficient classroom management in which it proactively addresses problem behavior. (Sugai \& Horner, 2002). Effective classroom management strategies will support and facilitate teaching and learning. It is basically based on the principle of establishing positive classroom environment which help encompassing teacher - student relationship. By which the teacher tries to focus on preventive rather than reactive classroom procedures. We cannot avoid from the fact that daily practice in education has changed very rapidly in which it has greatly emphasized on students- centered and not teacher centered any longer. In addition, the advancement of technology such as the use of laptop, mobile phone, I-pad, tablets and internet connection has caused a large impact on the need of teacher's classroom management skills. Related to virtual classroom, 'proactive' should be carried out by the teacher in order to prevent unexpected nuisance occurred in her virtual classroom. The challenge to establish and maintain classroom management strategy in virtual classroom has caused the teacher to find solution to overcome those challenges. 
It is widely confirmed by teachers all over areas in Indonesia that online learning has caused teachers and schools intermittently reacted. This due to the fact that schools and teachers have limited knowledge about the tools and Information Communication Technology (ICT) to run online learning and more importantly is the cost (Renggayana, 2018). This truth was revealed through the date in this study as follows. Both traditional and virtual have their own challenges in teachers' classroom management, however in virtual classroom teacher should be more active in preparing the devices and the application for learning whether she would like to use Zoom meeting, google meet or What up group. This proactive action will help the teacher efficiently in managing her teaching hour, since she has shared the link before the class time, and this will help her much more organized.

In virtual classroom the teacher teaches directly to the core of the material because of limited time. This is a kind of time restriction in which the teacher cannot elaborate the material or even cannot interact or greet the students one by one properly because of the time. The researchers think that this restriction is due to the limitation of teaching hour 30 minutes per session. Actually, virtual classroom should be more interactive, since it accommodates all teaching activity: teaching materials, graphs, simulation, evaluation even feedback are structured in interactive multimedia learning connected to the internet.

Some other problems in online learning are internet connection and not all students have cellphones. For students in remote areas, they often experienced weak internet connection, because of only a few numbers of internet tower built up in that area. This is also coincident with the students' affordability to buy devices like mobile phone, I-pad or laptop because of their economic condition especially during Pandemic COVID-19 where most students' parents got decreasing income due to the global pandemic economic situation. To overcome these problems, schools and teacher must should be able to utilize any available facility provided by the government. Related to internet connection problems and also internet quota, our government through Minister of Education Culture Research and Technology carried on the free internet quota program for students, university students, teachers and lecturers. For 2021 this government aids will be distributer in September, Oktober until November 2021 (Kompas, 2021).

What referred to as challenges in this study had similarly been identified in one study conducted by Biswas \& Nandi (2021). They stated that some challenges in teaching virtual classroom derived from either internal and external factor from perspectives teacher and students. Below are teacher's challenges in teaching virtual classroom:

a. Lack of interest within teachers to learn and adapt to new-learning situations.

b. Unwillingness to learn and apply ICT in classroom.

c. Age old belief to the method of chalk and talk method of teaching

d. Time consuming with respect to preparation of lecture materials.

e. Grasp over language often act as barrier as virtual classroom.

f. Difficulty in preparing study material with the medium of instruction.

g. Fear of students looking into inappropriate sites.

h. Inability to motivate students to use virtual learning mode.

i. Due to the absence of face-to-face contact, the bond of teacher and students are not formed (Biswas \& Nandi 2021, p. 335).

On the other hand, some challenges derived from students' factors taken from Biswas \& Nandi (2021, p. 335) are outlined as follows:

a. Lack of awareness among the students regarding the Lack importance and benefits of virtual learning.

b. Lack of interest and motivation among the students to learn.

c. Lack of interest and motivation among the students to use it for learning purpose, although they use latest technological gadgets.

d. Finance condition of the students is an important challenge.

e. Sustenance of the interest to attend virtual classes. 
f. Inadequate practice on their part also results in forgetting the techniques.

g. Language problem is a challenge. Inability of students to understand and use English is still a challenge for the students of our country

Followed by another finding that students are lazier and less interaction between teachers and students in virtual classroom. Indeed, it should be admitted that lack of interaction is caused by the absence of face- to- face contact or inability of the teacher to establish the 'bonding' between she and her students. The teacher cannot see the students' body language directly, their mimic, their facial expression, even cannot communicate well during the class. To overcome this problem the teacher should establish creative way to make her lesson interesting and engage the students in various virtual classroom activities. Moreover, the teacher should be able to initiate and maintain classroom interaction appropriately, since classroom interaction happened virtually. To overcome this the teacher uses her appropriate classroom management in which she can check the students' attendance at the beginning and at the end of the lesson, then giving some quizzes at the end of the lesson to make the students more enthusiastic in learning and also give points as bonus for their daily scores. As it is in line with Ring \& Mathieus's opinion in Renggayana (2018) that online learning should have high authenticity in which the students should learn in workplace context, high interactivity and high collaboration. Moreover, in most Indonesian online classes, they are always carried synchronously, where the teacher and students are in virtual class at the same time though from different places.

According to Sagala (2000), classroom management activities are not simple activities or routines that can be carried out carelessly. In reverse it should be taken seriously. Therefore, to improve their ability to manage learning, teachers must understand the aspects contained in classroom management and be skilled in implementing them in the classroom. Teachers need strategies so that the teaching and learning process is successful. This strategy is very decisive because it is the teacher's way of carrying out an activity to achieve the goals of the learning process. The teaching strategy will help teachers to achieve the goals of the teaching and learning process effectively.

The development of IT technology and the internet has become the basis of the virtual classroom. Thus, virtual classrooms have some internet characteristics that traditional classrooms do not have. For example, there are no restrictions on time, place, distance, and it is more convenient for students and teachers to get more information from the internet (Sufeng \& Song, 2013). For Indonesian teachers, they do not have any option in the Pandemic situation which means that they have to learn ICT and use application program in their own virtual classroom teaching.

\subsection{Type of Classroom Management used in Virtual Classroom}

Research Question 2: What type of classroom management are used in virtual classroom? There are some styles employed by the teachers in managing their classroom. These styles are widely affected by the teachers' personalities such as, psychological traits, bravery, academic, social, economic and cultural background. In addition, some other factors such as, the students' characteristics and backgrounds, properties of the educational situation would affect the teacher's style in managing class as well. Thus, the teacher's management style would profoundly be affected by some factors mentioned above that caused them to adopt the style in their classroom (Ali \& Ahmad, 2014).

Based on some of research results relevant to the focus of this study aiming at investigating the popular managerial styles of the teachers, there are four main styles of classroom management:

(1) Traditional management style, (2) Autocratic management style, (3) Democratic management style, (4) Leisurely management style, and (5) Maye's Conceptualization model.

The management styles used by teachers in this virtual classroom is a combination of democratic management style and leisurely management style, and thus it comes up with a new proposed model of virtual classroom 
management style called Maye's Conceptualization model.

\section{- Democratic Management Style}

Classroom management styles that have an impact on the effectiveness of learning. When students are real, they sense their value and status, and care about achieving goals. The democratic style teacher maintains good relations between her and his students. When teaching teachers build good relationships with their students, so that the virtual classroom is not too rigid. In giving teacher values that are very democratic, the teacher always asks questions in the middle of learning in the virtual classroom, which is a strategy so that students still pay attention to what the teacher says, the teacher gives the opportunity to students who can answer, but if no one wants to answer, the teacher immediately points to the student. Students who can answer the questions get a grade, that is included in the daily score.

\section{- Leisurely Management Style}

When the teacher gives more freedom to the students to do the right things and the things that suit them regardless of imposing his or her view to the students, it is the characteristics of leisure management style. Moreover, he or she enjoys a pleasant personality which mainly caused by the students' respect and appreciation. In teaching the teacher applies a relaxed but assertive teacher type, the teacher gives the opportunity to children to express their opinions about the material being discussed, tell stories privately, but students remain polite and respect their teachers.

The combination of democratic management style and leisurely management style formed a proper classroom management style in the virtual classroom. In other words, we may say that this is the virtual classroom management style. As it is stated previously that effective classroom management will lead to effective classroom teaching and learning in which the act of supervising relationship, behaviors, instructional settings and lessons for students in the classroom. Furthermore, preventive classroom management can decrease classroom problems by which good planning, interesting and relevant lessons, and effective teaching can be promoted in teacher's virtual classroom. Thus, in virtual classroom we need not only proactive activity, but also preventive activity to maintain effective classroom management. In other words, the teacher who is in charge of teaching must have acquired the combination of knowledge and skills for effective teaching.

However, for a virtual classroom, we require virtual pedagogy in which effective use of virtual learning pedagogical frameworks lead to the development of the students' high order thinking skills. This skill could be achieved by reflective and collaborative work and assessments using tools such as groups, asynchronous, discussion boards and synchronous communications - virtual classrooms and conference rooms.

\section{- Maye's Conceptualization Model}

In this paper, the researchers proposed one model which is relevant to the focus of the study that is Maye's Conceptualization model (Rufai, Alebiosu \& Adeakin, 2015). There are three stages in this model which are called the conceptualization cycle.

Stage one or Level one: e-learning conceptualization. In this stage the learners are helped to rise their awareness of what they need to learn and understand. In this stage, the teacher upload resources, such as Power Point files or word handouts, to a Web Based Learning Environment (WBLE) such as Moodle or any Learning Management System (LMS). The purpose is to provide students with information they need to understand and learn if they are to be successful on that particular course. This stage is called as "Primary Courseware".

Stage two: e-learning construction stage (students perform task):

In this stage, the learners are provided with meaningful online tasks that allow them to apply the concepts outlined to them in the conceptualization stage. In this model, this stage is marked as "Secondary Courseware". The form of this course takes the form of online self-marking tests which give feedback to the students based on their responses or final score.

Stage three: e-learning dialogue stage (students given feedback)

In this stage, learning using technology is usually took place in which its benefits could be observed in terms of either the students' experience or efficiency gains in online course. The students are allowed to interact with one another in order to comprehend the topic being discussed which caused the classroom's culture is less depressed. The 
students are allowed to participate in effective Computer based Communication (CMC) with their teacher and their classmate. Fortunately, the concepts outline in stage 1 and applied in stage 2 can be asessed via online discourse. If any misconception occurred, these can be solved through meaningful online two-way communications.

\section{Conclusion}

This research was intended to find out the challenges of teachers in classroom management in virtual classrooms. This research also aims to find out what classroom management the teacher uses in virtual classroom.

Shifting from traditional classroom to virtual classroom has caused some challenges that must be overcome by the teacher. The result from data analysis, it showed that the teacher had many challenges in this virtual classroom, such as a student learning atmosphere that was not conducive to learn; students turned off their cameras during virtual learning; some students turn off the sound; inattentive students where they were in front of the camera but their attention was not to the teacher; being expelled from the virtual class because of the internet connection problems; and the worst among all was that unavoidable obstacles during virtual classroom learning. Therefore, it is profoundly required for teacher to establish and maintain good classroom management in order to have effective classroom teaching. Time constraints are also an obstacle in this virtual classroom because teachers cannot explain more but get to the core of the material due to limited time in virtual classrooms. Coincidently, these typical Indonesian virtual classrooms embraced similarity with some virtual classroom in India where the teachers are mostly lack interest to learn and adapt to new-learning situation because of the Pandemic, unwillingness to learn and apply ICT, ineffective teaching preparation, inability to motivate students to virtual learning mode, and inability to establish a "bonding" between teacher-students in her virtual classroom.
The teacher must exert her strength to overcome these challenges by taking several steps in preparing her virtual classroom management: a) joining the virtual classroom earlier; b) checking the students' attendance first; c) optimizing the teacher-students interaction during whilst- learning and post learning activity; and d) giving quizzes at the end of the lesson to make the students are more enthusiastic in learning.

The most important thing as the focal point in this research is that proposing style for virtual classroom management which embraced democratic management style and leisurely management style and we call it "Maye's Conceptualization Model". This model consists of three stages: Primary Courseware, Secondary Courseware, and Giving Feedback. It seems that this virtual classroom management initially help the teacher to focus on managing her virtual classroom according to her needs.

\section{Suggestions}

Based on the research findings, discussion and the conclusion of the study, some suggestions are offered by the researchers to those who will carry out research in the similar field for the future. For English teachers, the researchers suggest that teachers should establish better virtual classroom management in which the students can enjoy participating in the teaching and learning process in virtual classrooms. In addition, teachers must be more creative with new methods, games and other teaching techniques to make students more active in learning English in virtual classrooms.

For further researchers, the researchers suggest that other researchers would try to implement the Maye's Conceptualization model for virtual classroom management to see whether each stage accommodates the teacher and students- interaction in the virtual classroom learning. teachers have better virtual classroom management. 


\section{Biographies}

Ridha Mardiani obtained her Doctorate degree in English Education from Indonesia University of Education in 2010. She is a civil servant of LL DIKTI IV assigned to Sekolah Tinggi Keguruan dan Ilmu Pendidikan Pasundan in English Education Study Program. Her research interests are in the area of TEFL, EFL Methodology, Literature in ELT, and Intercultural Communication. She has presented her paper in International Seminar and Conferences such as TEFLIN, CONAPLIN, ICCLLS Burapha University Thailand, ILAC Suan Dusit Rajabhat University. Her latest presentation is with Galeri Sah Alam SAFAS 2021 UiTM Malaysia.

Ridha Nurul Azhar was graduated from English Education Study Program, STKIP Pasundan in 2020. She has been able to complete her research paper during Pandemic COVID-19 which gave her meaningful experience in research education. Now, she is working at one company in Cimahi, West Java

\section{References}

Biswar, R.A. \& Nandi, S. (2020). Teaching in Virtual Classroom: Challenges and Opportunities. International Journal of Engineering Applied Sciences \& Technology. Vol. 5, Issue 1. ISSN No. 2455-2143, pp. 334-337. Published online May 2020 in IJEAST (http://www.ijeast.com).

Cresswell, J.W. (2014). Research Design: Qualitative, Quantitative and Mixed Method Approaches ( $4^{\text {th }}$ edition). Thousand Oaks, CA: Sage.

Fusch, P., Fusch, G., \& Ness, L.R. (2017). How to Conduct a Mini-Ethnographic Case Study: A Guide for Novice Researchers. The Qualitative Report. Vol. 22, No. 3.

Headden, S. (2014). Beginners in the classroom: What challenging demographics of teaching mean for schools, students, and society. Carnegie Foundation for the Advancement of Teaching. http:// www.carnegiefoundation.org/wpcontent/uploads/2014/09/beginners_in_ classroom.pdf
Ingersoll, R. M., \& Smith, T. M. (2003). The wrong solution to the teacher shortage. Educational Leadership, 60(8), 30-33. Retrieved from http://citeseerx.ist.psu.edu/viewdoc/do wnload?doi= 10.1.1.182.106\&rep=rep1\&type=pdf

Holloway, I., Brown, L., \& Shipway, R. (2010). Meaning not measurement: Using ethnography to bring a deeper understanding to the participant experience of festivals and events. International Journal of Event and Festival Management, 1(1), 74-85. doi:10.1108/17852951011029315

Korucu, A.T. \& Alkan, A., (2011). Differences between m-Learning (mobile Learning) and e-Learning, basic terminology and usage m-learning in education. Procedia. Social and Behavioral Sciences 15:1925-1930 DOI: 10.1061/j.sbspro.2011.04.029

Kompas. (2021). Jadwal Penyaluran Kuota Internet Gratis Kemendikbud 2021, Mulai September hingga November. Retrieved from kompas.com

Langdon, C. A. (1999). The fifth Phi Delta Kappa poll of teachers' attitudes toward the public schools. The Phi Delta Kappan, 80(8), 611-618. https://www.jstor.org/stable/20439521

Langdon, C. A., \& Vesper, N. (2000). The sixth Phi Delta Kappa poll of teachers' attitudes toward the public schools. Phi Delta Kappan, 81(8), 607-611. https://www.jstor.org/stable/20439737 Lankford, H., Loeb, S., \& Wyckoff, J. (2002). Teacher sorting and the plight of urban schools

Moore, J.I., Deane-Dickson, C. \& Gaylen, K. (2011). E-learning, online learning, and distance learning: Are they the same? The Internet and Higher Education 14(2): 129-135. DOI: 10.1016/j.ihedue. 2010.10.001.

Mutqonah, R. \& Hidayatullah, T. (2020). Impelemtasi Pembelajaran Daring (Program BDR) Selama Pandemi COVID-19 di Provinsi Jawa Barat. Jurnal PETIK Vol. 6, No. 2, Sept 2020, hal 86-96.

Palmer, C., \& Amanda, B. (2006). A Brief Introduction to Qualitative Research. The Canadian Journal of Medical 
Radiation Technology, 37(1), 16-19. DOI: $\underline{10.1016 / \mathrm{S} 0820-5930(09) 60112-}$ $\underline{2}$.

Range, B. G., Duncan, H. E., Scherz, S. D., \& Haines, C. A. (2012). School leaders' perceptions about incompetent teacher implications for supervision and evaluation. NASSP Bulletin, 96(4), 302322.

https://doi.org/10.1177/019263651245 9554

Renggayana, T. (2018). E-Learning dan Online Learning Itu berbeda Konsep dan Pengertian. Retrieved from https://renggayana.com

Rufai, Alebiosu \& Adeakin. (2015). A Conceptual Model for Virtual Classroom Management. International Journal of Computer Science Engineering and Information Technology (IJCSEIT), Vol. 5, No. 1, Feb 2015. DOI: 10.5121/ijcseit2015.5103.

Scrivener, J. 2011. Learning Teaching 3rd Edition. Dahaka: Macmillan.

Wang, A. Y. (2001). Online Lectures: Benefits for the Virtual Classroom. T.H.E. Journal

Setyowati, I. 2017. Classroom Management Applied In Teaching English By The Tenth Grade English Teacher Of SMA N 1 Wonosari In The Academic Year Of 2015/2016. Thesis. Surakarta. Islamic Education And Teacher Training Faculty. The State Islamic Institute of Surakarta.

Sokal, L., Smith, D. G., \& Mowat, H. (2003). Alternative certification teachers' attitudes toward classroom management. The High School Journal, 86(3), 8-16. https://doi.org/10.1353/hsj.2003. 0004

Stoughton, E. H. (2007). "How will I get them to behave?": Preservice teachers reflect on classroom management. Teaching and Teacher Education, 23(7), 1024-1037. https://doi.org/10.1016/j.tate. 2006.05.001

Sufeng, Y., \& Song R.2013. Virtual Classroom and Traditional Classroom. International Conference on Education Technology and Management Science, 114-116.

Sugai, G., \& Horner, R. (2002). The evolution of discipline practices:
School-wide positive behavior supports. Child \&

Family Behavior Therapy, 24, 23-50. doi:10.1300/J019v24n01_03

White, K. L. (2009). Meztizaje and remembering in Afro-Mexican communities of the Costa Chica: Implications for archival education in Mexico. Archival Science, 9, 43-55. doi:10.1007/s10502-009-9102-5

Westling, D. L. (2010). Teachers and challenging behavior knowledge, views, and practices. Remedial and Special Education, 31(1), 48-63. https://doi.org/10.1177/074193250832 7466

Zhang et.al. (2004). "Can E-learning replace Classroom Learning?" Communication of the ACM 47(5): 75-79. DOI: 10.11.45/986213986216 